Bulletin of Advanced English Studies - Vol. 3, No. 1 , 2019, pp. 12-20

e-ISSN 2617-6459, p-ISSN 2617-6440

Available online at http:// www.refaad.com

https://doi.org/10.31559/baes2019.3.1.2

\title{
The Time Regulation Institute and the Quest of Modern Turkishness
}

\author{
Saman Hashemipour \\ Girne American University, The Faculty of Humanities, Turkey \\ smnpour@gmai1.com
}

\begin{abstract}
In Turkey Ahmet Hamdi Tanpinar is the subject of countless analyses and critiques. In 'The Time Regulation Institute,' Tanpınar offers a genuinely fascinating and engaging narrative set in postOttoman Turkey to the readers. The novel discusses the opposites; a family of wealthy aristocrats who are working hard to fix the old way of life against the entry of modern Western culture and parallels it with the days of the young Republic. The novel speaks of the heart and soul of a nation. The main character, Hayri, established the institute, but he is not a respectable person, and his personality is not fitted because of his father. He is stuck between old and new. The novel's protagonist wanders from one temporal-historically absurd situation to the next. The meaning of this novel lies in the way it both examines the cultural effects of the reforms- without producing new logocentrism- and controlling the fantasy through its language.
\end{abstract}

Keywords: Tanpinar, Modernization, Tanzimat, Turkish Identity, Turkish Novel

\section{Introduction}

Modern Turkish literature has its roots in the social, cultural and literary developments of the Tanzimat reform period in the Ottoman Empire in the course of the nineteenth century. Modern and the following contemporary postmodern literature are combining elements of genre parody and pastiche, new media, absurdist and irony, developing a self-referential style that called attention to its own artifice. In Europe, the history of literature in the Modern period starts with the Age of Enlightenment in the eighteenth following the Renaissance periods. Out of Europe, the Modern period begins in Ottoman Turkey with the Tanzimat reforms (the 1820s) and in Qajar Persia under Nasser al-Din Shah (1830s), the establishment of the British Raj in India, in Japan with the Meiji restoration, and in China with the New Culture Movement. The Tanzimat reform encouraged Ottomanism among the different ethnic groups of the Empire, attempting to stop the nationalist movements within the Ottoman Empire. The reforms attempted to mix non-Muslims and non-Turks into Ottoman society by increasing their civil rights and permitting them equality.

\section{Modern Turkishness Rose from the Ashes of Tanzimat}

By giving a conclusion to the Millet system, the Ottoman Empire hoped to control its citizens and impose the changes to Great Powers as long as reforms were continuing and leaving them to reach these goals. During this period, many authors tried new literary genres and styles to overcome the tension which arose between Eastern Turkish, Western values and literary traditions that considered as the concepts of alaturka and alafranga. The literary output of this period mirrored the social transformations taking place in the Ottoman. Ataturk's reforms had far-reaching values for the new society and the development of language, literature and education. Stress on prose from the Tanzimat to contemporary literature influenced the shaping of a new society. Literature was a significant catalyst of westernization changes which conservative religious establishment was against it. Thoughtful reformers recommended a mixture of Eastern culture and Western technology. But 
intellectuals pressed for massive changes patterned by European descendants. New genres adopted from Europe gained power: fiction, drama for the stage, journalistic writing, the critical essay, and others. Translations and adaptations speeded the Europeanization of Turkish literature. Young poets came into contact with European aesthetic theories and values. Turkish poets experimented with forms, rhythms, and styles.

A reaction began to use words of Arabic and Persian origin. Although these projects and the new genres shortened the power of verse and poetry, they were to keep much of its rule over Turkish intellectual life. Poetry developed social awareness to gain independence from external political domination. Ziya Pasha, Şinasi, and Namık Kemal emerged as champions of nationalism. Recaizade Ekrem and Abdülhak Hâmit Tarhan echoed the French romantics. Later, the poetry of the Tanzimat Period had the task of fixing forms, style, and content by giving voice to civil disobedience. Its authority-despite censorship — often acted as activists for reform and social modernism, as a rebellion against tyranny. Poetry became a standard way for concepts as justice, nation, reform, dominion, modernization, freedom, progress and rights. The social poets of the era made a useful view of poetry to criticize against some of the rooted Oriental traditions and the cruel Ottoman society. Because of the poems of protest or criticism, many poets were punished and sent into exile. Tanzimat brought into Turkish poetry was a brave new matter, with a clearly formulated political content, and criticized the sultan and his oppressive regime, for freedom and justice. Talat Halman describes the post-shrinking Ottoman Empire period as;

In 1839, the Tanzimat (Reforms) Period was ushered in: legal, administrative, and

cultural changes were introduced in quick succession. Literature was both a concomitant to and a major catalyst of these changes. The conservative religious establishment waged all-out war against Westernization, however. Cautious reformers recommended a synthesis of Eastern culture and Western technology [...] The decline of the Ottoman Empire reached a critical point by the middle of the nineteenth century. Younger Turkish intellectuals started seeking the empire's salvation in technological development, political reform, and cultural progress fashioned aft er

European prototypes. (Halman, 2011, p. 63-64)

Open to the growing literary aesthetics from diverse civilizations, Turkish culture succeeded in developing its characteristics. It fell onto its own established characteristics; although it was flexible enough to welcome innovations or even revolutionary changes. Among literature that led Turkish literature, Hebrew, Chinese, Greek, Arabic, Persian, German, Indian, Irish, Spanish, and perhaps two or three others are cited. With the establishment of the Turkish Republic in 1923, modern Turkish literature gained more power. The leftist poet-playwright Nazım Hikmet (1902-63) revolutionized Turkish poetry and became a world-class figure. The woman novelist Halide Edib Adivar (1884-1964) made an impact, and some of the works written in English were published in England and the United States. The genre of fiction was dominated in the second half of the twentieth-century by Yashar Kemal whose creative production of novels came close to win a Nobel Prize in literature by him. That honour ultimately was won by a younger novelist, Orhan Pamuk, in 2006 - the first Nobel prize ever won by a Turk in any field of Art and science. Pamuk's honour stands as the finale of the Turkish nation's passion for literature for many ages. He was a messenger of future victories for Turkish poets, playwrights, essayists, and critics as well as fiction writers. It is well-known that poetry was the dominating genre of Turkish literature for about a thousand years. Later, in the twentieth century, it was hidden by fiction which established its domination in the present age.

Turkish literature is comprised of both oral and written texts, either in less perfect literary forms (such as that of oral folk literature in the Republic of Turkey today), or in its previous, highly stylized Ottoman forms that are the basis of much of the written 
core that was influenced by Arabic and Persian language and literature, and that used the Ottoman Turkish alphabet in Arabic and Persian script.(Hashemipour, 2019, p. 6)

Orhan Pamuk certainly played a significant role in awareness of Turkish authors; although, it would not be incorrect to assert that the novel genre in Turkey become dominant even without Pamuk's remarkable success. In his lecture to the Swedish Academy of the Nobel Prize, Pamuk stated that he hoped one day his novels "will be read and understood, because people all the world over resemble one another" (Pamuk, 2007, p. 413). Now, in the early twentieth-first century, Turkish verse seems to be suffering from tired blood. Today, the few respected Turkish literature figures got old, and younger authors have channelled their creative energies into fiction. Known publishers have been forced to cut the publication of poetry books and anthologies. Turkey is experiencing the drop that played chaos with the popularity and prestige of poetry in the English-speaking world — which several decades earlier happened in Europe and Latin America. Poetic creativity is outdone by the novel's current power. What mixes the problem is that most of the auspicious Turkish verses are puzzling, old-fashioned, and unreachable. A similar effect is observed in dramatic writing-in comparison with the plays that achieved success at the end of the twentieth century. Even the significant playwrights of that period-those who are still alive-have stopped writing plays. Thereby, writing talents who mightily are expected to write for the theatre are now concentrating on well-paid TV series or movies. Nook market in Turkey, anymore, is dominated by non-Turkish classics and translations of modern European and American hits.

\section{The Place of Tanpınar's Fiction in Turkish Literature}

For a millennium, creative writing had produced masterworks and scholars, academic critics, and professional reviewers started to produce modern works. Today, novels and short stories in Turkey can be ranked as world-class literary works. The modernist Yaşar Kemal, a Nobel Prize candidate for decades, is esteemed as a master of fiction and the Nobel laureate Orhan Pamuk continues to enjoy international popularity. The variety of creativity in the genre of fiction in Turkey is amazing. From realism to a stream of consciousness, from historical adventure to magical realism, from psychological doubt to epics, in half a century Turkish authors experienced almost the entire experience of European, American, and Latin American fiction. Moreover, imitating other works of literature, Turkish authors did their works with an authentic Turkish personality. In the early phase of the second millennium, Turkish literature stands as old and new, mature and youthful. It confidently looks forward to its future as a powerful face of world literature. Turkish literature has never been more wide-ranging or general as it is today. Following many decades of conscious experimentation, questing for new values, gaining more profound literary and human visions, Turkish authors are creating a reliable blend of national and universal elements. For example, Pamuk's works acknowledged Westernization as an essential factor to measure development, but do not turn their back on the Islamic heritage of Turkey. Turkification, Islamization, and contemporization identify Pamuk's questioning a universal human identity and of his privileging of Turkish Islamic and nationalist difference. Pamuk's writings accepted both Islamic and nationalistic views as integral parts of the Turkish cultural heritage and the anxiety of the loss of the old culture that might occur with their absolutism. Pamuk tries to state Turkish people are interrogated or suggestive at a historic moment of transition. They tend to be somewhat directive, prescriptive, and authoritative, to the extent of being almost logically radical. (Hashemipour, 2018, p. 120-1)

In the early part of the third millennium, the literature of the Turkish Republic can gain some impressive success and greatness in various genres, but it is faced with some disablements that could be summarized as: 
1. The cultural attack happened because of changes in sociopolitical institutions, faith, and technology;

2. Language crisis which is caused by new vocabulary entries. When the majority of Turkish words had Arabic, Persian, and French roots in 1920 new vocabulary entries regularly increased by 1970, and at the new century it is about 100000 dictionary entries;

3. A critical gap occurred because although some decent critical writings have published, Turkish literature still operates without any guidance of explicit aesthetic theories and systematic critical analysis;

4. Traditional gaps took place because of the noticeable absence of philosophy, types of tragedy, and psychological analysis in depth;

5. Extreme imitation of models, movements and major works have already developed in the West.

The second half of the twentieth century witnessed steps taken in literary criticism when Nurullah Ataç- fame as an impressionistic critic- reexamined the tradition of classical poetry and led the values essential in projects of new poetry; especially, The First New Movement. The most exciting and continuing influence made by Ahmet Hamdi Tanpinar (1901-62)- a noticeable Turkish littérateur and a powerful promoter of a generation of intellectuals who made a mixture of classical Turkish culture, French literature, and modern artistic sensibilities.

As a novelists and essayists of Turkish literature, Ahmet Hamdi Tanpınar, a member of the Turkish parliament and a professor of literature at Istanbul University wrote a complete critical history of Turkish literature in Ondokuzuncu Asır Türk Edebiyatı Tarihi [Turkish Literary History in Nineteenth Century], and an excellent essay on the famous neoclassical poet, Yahya Kemal.

Nazım Hikmet's innovations in poetic tastes throughout his life and after his death, by no means, established domination. Most of his contemporaries followed different courses: Some combined neoclassicism with urbanized versions of folk verse, and some like Ahmet Hamdi Tanpinar focused in simple lyrics of polite sensibilities expressed in orderly stanza forms and the traditional syllabic rhythms. Combining Eastern and Western cultures within his writings, Tanpınar followed the steps of Beyatlı and produced a critical cultural study, purified some of Beyatlı's aesthetics into clear poems written in syllabic verse. Yahya Kemal Beyatli played a vital role in the background of Tanpinar's works. In his poetry, Yahya Kemal used Turkish classical music as a textile for his works. Both in his poetry and novels, psychological analyses, history, the specifics of the time, the bound between the society and the individual, dreams and the problems of civilization took a high degree.

Ahmet Hamdi Tanpinar was born in Istanbul in 1901, graduated from Istanbul University, Faculty of Literature and worked as a literature teacher in Anatolia and Istanbul. For a period he gave lectures in the Department of Turkish Language and Literature at Istanbul University. His poems were published in many magazines and newspapers. The Time Regulation Institute printed in 1961 as the fourth novel. Formerly, he wrote stories, essays, articles, biographies, letters, poems, and novels up to 1962 when he died in Istanbul. One of his most significant works, among others, is a novel entitled Saatleri Ayarlama Enstitüsü [The Time Regulation Institute]. The book has been widely accepted as an ironic criticism of the bureaucratization process, and the novel can be studied from quite different perspectives. The novel is an excellent psychological analysis of a man who suffers from being unable to adapt himself to modern times. Besides, other characters of the novel are struggling in quite a weird manner, and in this way, the fact of bureaucratization is combined into a broader problem, which is modernization. In this way, the concept of time gives a philosophical taste to the novel. 


\section{The Story of a Piggy in the Middle of the Past and Present}

When Hayri İrdal was ten years old, his uncle gave him a watch. This watch made a significant impact on him. Gradually, dealing with clocks becomes a passion for Hayri İrdal. Later, he becomes an apprentice to a watchmaker. Hayri İrdal starts to examine, untie and tamper his uncle's gift; at the time, his curiosity for watches starts to increase. He spends most of his time in Nuri Efendi's clock room. However, one day, Hayri İrdal's aunt is passed away. Because of the economic situation of Hayri İrdal's family, his dad is tempted to steal his sister's properties to sellinstead of dealing with his sister's funeral ceremony. When the aunt was about to be buried, she is revived. Thereafter, she sent Hayri İrdal and his father out of the house. When Hayri İrdal is discharged from the army and back to Istanbul, he observes that everything has changed. He learned his father is passed away, and an unsuccessful struggle to find a new job starts. After a while, he is married to Mister Abdüsselam's daughter, Emine and they give birth to Zehra. As Mister Abdüsselam's mother's name was Zehra, and he pushes the name of the newborn baby as Zehra, not other. He soon starts to call her as his mother. From here on, everything becomes funny when Mister Abdüsselam writes so many testamentary letters for Zehra.

Although there is no inheritance around, everyone is blaming Hayri İrdal and Emine for that. One day Hayri İrdal wants to tease his colleague. He exaggerates about a matter, his colleague believes and the issue is spread rapidly. Hayri says it was a joke, but people do not believe in him anymore. They take Hayri to court again. He says it was a joke, but the court also did not believe in him. The court sends him to forensic meditation. In there, Hayri meets Dr Ramiz. Hayri stays in the hospital for ten days; where he starts to repair watches. The doctor puts the diagnosis at the end of ten days: the father complex. He would be discharged after a while. Hayri İrdal's second child, Ahmet, is born, but later, Emine dies after getting an illness. In the sequel, Hayri İrdal gets married to Pakize, who is continually used to watch movies, and thereby, they always go to the cinema. Sometimes Pakize thinks she is a movie character and acts as an actress in a movie. Against Hayri, Pakize makes pressure on Zehra to get married to İsmail.

One day in the coffee house, Hayri was giving the stink-eye to İsmail when Dr Ramiz and Halit Ayarc1-who met for the first time-entered. From this point on, Hayri İrdal's life is divided into two parts; before and after meeting Halit. During the conversation, Dr Ramiz mentions Hayri as a watchmaker. Halit takes out a broken clock from his pocket and asks Hayri to fix it which makes Hayri excited. They go to repair the watch, and after that, three friends go to dinner together. At the dining table, Hayri describes his life to Halit Ayarc1. In those days, a small apartment is planned to form the basis of the Time Regulation Institute. In the department, Hayri is the manager, Halit Ayarc1's niece Nermin is the senior manager, and Halit is the organizer. Institute was already completed in three months. During a visit, Halit informs Hayri about writing a book, which tells the story of a watchmaker called Ahmet Zamani Efendi. Halit forces Hayri to write such a book with the same theme. After a period, the book released as Ahmet Zamani Efendi's life and Works. One day, a person says them that he is Ahmet Zamani Efendi's grandson; they made a ritual to conjure up Ahmet Zamani Efendi's spirit.

Cemal spreads rumours that the content of the book is not real. The fame of the book has shaken, and in a series of events, finally, Tayfur kills Cemal. The building of the institute requires the design of clockwork from the inside and outside. Hayri İrdal and his wife, Pakize, decide to build and design it. People love it, but as a matter of fact, this project was a big hit. The next project of Hayri İrdal was not approved by anyone. People do not want to live in the homes Hayri İrdal constructed. Halit Ayarcı moves away for a while, and when he comes back, Halit and Hayri start to play backgammon. But, Hayri finds Halit as a stranger to him. Then, Halit leaves and makes an accident that night and dies. This is the last time Hayri İrdal visited Halit. 


\section{The Institute of Modernization}

Hilal Kaya reminds that before Tanpınar, many literary people could not produce "shed light on the complexities of the Turkish experience of modernization" because their works were only analyses of modernity through supporting or rejecting Westernization and not more. (Kaya, 2018b, p. 104) Hikmet Kocamaner argues that like his contemporaries, "Tanpinar also reflected upon the incongruities between Western institutions and values and the Ottoman/Turkish ones. (2009) He says Tanpınar's critique was not limited to this "specific analysis restricted by a geo-cultural distinction between the East and the West" (2009) Similarly, Hilal Kaya reminds that like many of his contemporaries, Tanpinar "anathematized the lack of harmony between Western and OttomanTurkish values and mentalities." (2018b, p. 42) Tanpınar's novel is critical of the institutes, organizations, agencies and the system of bureaucracy established as a part of the modernization project of Turkey. Turkish modernization, as suggested by The Time Regulation Institute, is not a process of linear progress but a more complex process including alienation of individuals and displacement of identities. From this perspective, The Time Regulation Institute is a novel which reminds us of the significance of the idea of Multiple Modernities and the idiosyncratic characteristics and complexities of Turkish modernization-which is by nature heterogeneous. (Kaya, 2018a, p. 113)

The emergence of modern time with the founding of the Republic of Turkey in The Time Regulation Institute is identified wholly by Tanpınar through the elites of the early Republic who believed the new Republican Turkey is separated from the Ottoman past. That was precisely the nature of the process that unfolded in the Ottoman Empire during the nineteenth century. Starting in the late eighteenth century, experimenting with new techniques of time organization have started in Ottoman domains to develop efficiency and regularity to obtain efficient time organization through methods that increasingly relied on mechanical clocks and time tables in the education system, systems of transportation, communication, and commercial firms. These changes closely connected to the notion of progress to reach a universal timeline towards the future. At the middle of the nineteenth century, Ottoman intellectuals and officials anymore began to use this model (Wishnitzer, 2015, p. 379-400).

Wishnitzer says, "Like Ahmed Haşim before him, and like a number of Egyptian and Indian writers, Tanpınar contrasts indigenous time with the foreign one that took over the country and robbed it of its past and identity." (2015, p. 399) Tanpinar's novel is full of fantasies, and the boundaries between the actual and false in the novel are not discovered. The whole plot is told by the protagonist who has "a very flexible, and functional, understanding of truth." (Wishnitzer, 2015, p. 394) Ottoman time is portrayed as being closer to "pure duration" and for Nuri Efendi, failing to set one's clock is both a social crime and a religious sin (Wishnitzer, 2015, p. 391). Tanpinar warns about "the power of modern institutions and their ability to impose a single truth, a single time, and a single historical narrative," and like yesterday's clocks, "yesterday's people were not subject to modern systems of homogenization. They were not forced to internalize dictated truths about a national past and were more free to fashion themselves by themselves. Their fabrications were humbler, closer to their own selves." (Wishnitzer, 2015, p. 395-6) Wishnitzer wrote,

unlike in the Egyptian and Indian cases, where the intellectuals were writing against the time of a foreign occupying force, Tanpinar was criticizing the political elite of his own country. The boundaries between the 'ours' and the 'theirs' are much more

blurred, as is the boundary between the present and the past. While the novel contrasts Republican and Ottoman times, the historical examination has shown that 'modern time' was actively promoted already in the late Ottoman period and that Tanpınar, who was born into this mode of temporality, could not think entirely outside of it. $(2015$, p. 399-400) 
Selim Kuru finds the novel as the story of individuals in modern societies in an imaginative way. He says the novel is admired for discussing modernity and should be studied on Turkish literature and Middle Eastern literature and cultures classes (2002, p. 260) Gülşah Şişman says a new page is opened in Hayri İrdal's life when he started at the Time Regulation Institute with Halit Ayarc1 whose task is to set all the clocks of the city. Although earning money is satisfying for Hayri İdal, but satire about social life and the bureaucracy is reflected in the weird situation of unrecognizable logic of bureaucracy and "the depression of society caused by civilization shift." (2017, p. 153) This is a good example by Tanpınar's in analyses of time;

Everyone knows that in former times our lives revolved around the clock. According to what I learned from Nuri Efendi, the best customers of Europe's clockmakers were always Muslims, and some of the most pious Muslims were to be found in our country.

The clock dictated all manner of worship: the five daily prayers, as well as meals during the holy month of Ramadan, the evening iftar and morning sahur. A clock offered the most reliable path to God, and our forefathers regulated their lives with this in mind. (Tanpinar, 2013, p. 21)

The conflict between traditionalism and modernity in the novel is revealed with the compare of Ottoman and Republican period. Hayri İrdal lived in both constitutionalism and Republican period, and he neither can get rid off the past, nor wholly accord with it; as he cannot solve his problem with the past and "stucked with history passion through personality of this half insane character" (Korkmaz, 2007, p. 433) he cannot be adapted to the present. İrdal becomes modern by getting out of his traditioner manner when he asserts, "I applaud the modern man, and I too enjoy modern comforts and modern architecture;" (Tanpinar, 2013, p. 55). Later, he says, "Today we live in what is called the modern world! And look at the state of those who deny it!" (Tanpinar, 2013, p. 295) Halit is being condemned as a Republican intellectual who approves modernisation "with no strings attached" but misunderstands it. (Şişman, 2017, p. 156) Nuri Efendi says, "For there's no such thing as the present: there is only a past, and a future at its beck and call." (Tanpinar, 2013, p. 86) Tanpinar reflects his ideas through his characters;

It's been given many names, but first and foremost it is the age of bureaucracy. All the philosophers, from Spengler to Kieserling, are writing about bureaucracy. I would go as far as to say that it is an age in which bureaucracy has reached its zenith, an age of real freedom. Any man who understands is a valuable figure. I am in the process of establishing an absolute institution - a mechanism that defines its own function. What could be closer to perfection than that? (Tanpinar, 2013, p. 286)

The Time Regulation Institute consists of four parts which are titled "Great Expectations," "Small Truths," "Towards Dawn" and "Every Season Has an End." The "Great Expectations" is an ironical allusion to the Dickensian bildungsroman in which Hayri narrates how his personal growth already happened. Kaya mentions that Tanpınar demonstrates "the Turkish project of modernization," or, the occurring social transformation of the Ottoman Empire into the Turkish Republic. He mentions in the first chapter, titled 'The Great Expectations,' Tanpinar describes "the project before the Tanzimat." Besides, the second, 'Little Truths,' Tanpınar "signals the increasing popularity of the project during the Tanzimat" its falling "in the third 'Toward the Dawn' and its breakdown in the last "Every Season Has its End;"' through which, Tanpinar "considers the beginning and the end/failure of the project of modernization in Turkey." (Kaya, 2018b, p. 42)

Pankaj Mishra mentions that The Time Regulation Institute explodes "the obscure sufferings of people in less 'developed' societies- those who, uprooted from their old ways of being, must languish eternally in the waiting room of history." (2015, p. 1) Tanpınar describes absurd situations by characters than language. Riker wrote, "There are not many belly laughs, or even jokes, but rather in which hypocrisies are laid plain." (Riker, 2018, p. 1) Atalay Gündüz reminds that in the novel, the preliminary dual opposites put forward Tanpınar's thesis and play an important role in the 
development of his satire. The most central of these is the contrast between the doctor Ramiz, who forgets to do the requirements of his profession when he pursues great solutions and miracles with Nuri Efendi, who patiently bent over his craft. (2009, p. 249)

Kaya wrote the distinction of the relationship between Turkish people and their past happened abruptly to fulfil the project of modernization in Turkey immediately orchestrated by the government and "caused a crisis in people's identity." (2018b, p. 43) In this sense, Turkish people "keep waging war on the concept of time: as a result of the modernization project of Turkey, the modern Turkish citizen feels that $\mathrm{s} / \mathrm{he}$ fell behind the 'modern/Western' time (the feeling of belatedness)." (Kaya, 2018b, p. 43) Kaya wrote, "the feeling of belatedness is such a heavy load for the individual psyche that it leads him/her to experience the feeling of in-between-ness and eventually emotional crises." (Kaya, 2018b, p. 43) She says, "the understanding of time in narratives resting on the liberal tradition of modernity and the idea of progress, the modern individual has started to regulate his/her life according to regulated, objective, mathematical time" (Kaya, 2018b, p. 51)

The state-led Turkish modernization project is depicted in Tanpinar's novel through a time regulation institute that struggles to "modernize" citizens; and this struggle is epitomized through Hayri and Halit the Regulator's institute that demands people to synchronize their lives with that of their nation's. This simplistic account of the narrative of linear progress is satirized in Tanpinar's novel. Turkish modernization, as suggested by The Time Regulation Institute, is not a process of linear progress but a more complex process including alienation of individuals and displacement of identities. From this perspective, The Time Regulation Institute is a novel which reminds us of the significance of the idiosyncratic characteristics and complexities of

Turkish modernization - which is by nature heterogeneous. As one of those complexities, Tanpinar claims the fact that Turkish modernization created a crisis (buhran) in the shattering of the cultural connections of Turkish society with its own history. (Kaya, 2018b, p. 58)

\section{Conclusion}

Ahmet Hamdi Tanpınar was the most influential writer of the Republican period in Turkey by exploring how literature disorders the workings of Turkish national grammatology. The Time Regulation Institute provides us with a critical critique of the superior thought that we dictate our own language at will. Old Istanbul aristocrats, Turkish teashops, imperial diamonds, and magnificent mosques compared it with the almost non-descriptive portrayals of neighbourhood friendships, family relations, and local public figures that could be found in any city in Turkey. Constructed as the autobiography of a writer-citizen, the novel states the transition from Ottoman Empire to the Republic of Turkey. The novel registers writing in a censored Turkish, weak of its Arabic and Persian elements as an extraordinary experience, offering a literary picture of the social effects of the reforms.

\section{Biography:}

Saman Hashemipour: Associate Professor, read English Language and Literature at undergraduate level. He graduated in American Studies and completed his PhD in Comparative Literature. He is a lecturer in the Department of English Language and Literature and the Department of American Culture and Literature at Girne American University. 


\section{References:}

[1] Gündüz. A., Birbirimizi Kandırmanın Dayanılmaz Hafifliği: Saatleri Ayarlama Enstitüsü Çukurova Üniversitesi Sosyal Bilimler Enstitüsü Dergisi, Cilt: 18, Sayı: 1, (2009)

[2] Halman. T. S., ed, A Millennium of Turkish Literature: A Concise History. Ed. Jayne L. Warner. Syracuse, NY: Syracuse University Press, (2011).

[3] Hashemipour. S., Logoteunison: Literary Easternization in Orhan Pamuk's Works, Vernon Press: Wilmington, (2019)

[4] __ The Turkish Identity Crisis in "The New Life" by Orhan Pamuk, National Academy of Managerial Staff of Culture and Arts Herald, 2(1)(2018), 117-121.

[5] Kaya. H, The Modern in Huxley's Brave New World and Tanpınar's The Time Regulation Institute, Agathos, An International Journal Review of the Humanities and Social Sciences, (2018a), pp. 99-114.

[6] ___ The Time Regulation Institute as a Satirical Allegory, Sosyal ve Beşeri Bilimler Araştırmaları Dergisi, 19(2018b),37-59

[7] Kocamaner. H., Reconfiguring Modernity through Time: A. H. Tanpınar's The Time Regulation Institute, (2009), pp. 2.

[8] Korkmaz. R., Yeni Türk Edebiyatı El Kitabı 1939-2000. 4. b. Ankara: Grafiker Yayınları, (2007)

[9] Kuru. S., Book Reviews, Edebiyat: Journal of M.E. Literatures, 13(2)(2002), 251268, DOI: 10.1080/0364650032000143283

[10] Mishra. P., Ahmet Hamdi Tanpinar and the Waiting Room of History, The Guardian, Guardian News and Media, www.theguardian.com/books/2015/feb/28/ahmet-hamdi-tanpinar-the-time-regulation-instituteturkey-western-time, (28 Feb. 2015)

[11] Pamuk. O., Other Colours: Writings on Life, Art, Books and Cities. Trans. Maureen Freely. London: Faber, (2007).

[12] Riker. M., (14 June 2018), The Time Regulation Institute, by Ahmet Hamdi Tanpinar, The New York Times, The New York Times, www.nytimes.com/2014/01/05/books/review/the-time-regulation-instituteby-ahmet-hamdi-tanpinar.html.

[13] Şişman. G., Conflict Elements in The Time Regulation Institute by Ahmet Hamdı Tanpınar, International Journal of Multidisciplinary Thought, 6(2)(2017), 151-158.

[14] Tanpınar. A. H., , The Time Regulation Institute. (Translated by Maureen Freely and Alexander Dawe), New York: Penguin Books, (2015)

[15] Wishnitzer. A., (2015), Modern Turkey, Real Time, and Other Functional Fabrications in Tanpınar's The Time Regulation Institute, Journal of the Ottoman and Turkish Studies Association, 2(2), 379-400, https://doi.org/10.2979/jottturstuass.2.2.08 